\title{
Effect of Seedling Age at Trans Planting on Yield and Yield Components of Low Land Rice in Fogera Plain
}

\author{
Zelalem Tadesse \\ Ethiopian Institute of Agricultural Research (EIAR), Fogera National Rice Research and Training Center \\ (FNRRiTC), P.O.Box 1937 Fogera, Ethiopia
}

\begin{abstract}
Basically, there are two methods of rice plant establishment namely; transplanting and direct seeding .Direct seeding is the major method of rice planting being used in Fogera plain. However, transplanting is the major means of rice planting used in other parts of the world Therefore, field experiments were conducted in the area for two growing seasons during the 2018 and 2019 cropping years. The objective of the experiment was to study the effects of seedling age at transplanting on the yield and yield components of the crop under rain-fed condition. The treatments consists of six seedling age 0 , (dry seed as a control) 7 , (pre-germinated), 14, 21, 28, 35 days old seedlings were laid in RCB Design with three replications. Data were collected on yield and yield components of the crop. The data were subjected to analysis of variance using SAS software. Economic analysis was also performed to compare the economic advantage of the treatments. The results of the experiment indicated that seeding age was $(\mathrm{p}<0.001)$ affecting, Plant height, number of total tillers per $\mathrm{m}^{2}$ and number of filled grain per panicle. Whereas seedling age also $(\mathrm{p}<0.01)$ affecting panicle length, number of filled grain per panicle and grain yield. Moreover age of seedlings for transplanting $(p<0.001)$ affecting straw yield and thousand grain weight. The highest grain and straw yield (4.54 and $\left.11.7 \mathrm{t} / \mathrm{ha}^{-1}\right)$ was obtained from 21 days old seedling age respectively. The economic analysis indicated that 21 days old seedling age was the most profitable treatment with mean net benefit of 75132.0.Birr ha- ${ }^{1}$. Therefore it can be concluded that twenty one days old seedling age in the nursery was appropriate and recommended for transplanting method of rice production in Fogera plain.
\end{abstract}

Keywords: Seedling age, Transplanting, Low land rice, grain yield Economic analysis.

DOI: $10.7176 / \mathrm{JBAH} / 11-8-03$

Publication date: April $30^{\text {th }} 2021$

\section{Introduction}

Rice (Oryza sativa L.), is one of the most important food crops and is considered as a major source of calories for more than half of the global population (Carrijo et al., 2017), More than $90 \%$ of rice is produced and consumed in Asia (Subedi et al, 2019). The total world rice production has risen steadily from about 200 million tons (1960) to over 678 million tons (2009). In the 2010/2011 and 2011/2012, the world paddy productions were estimated at 691.3 and 713.8 million tons, respectively. Globally, 158.9 million hectare (ha) of rice was harvested during the 2011/2012 (USDA, 2012).

Africa has sufficient land and water resource to produce enough rice to feed its own population and, in the long term, generate export revenues. Rice cultivars, rice-based cropping systems and the rice itself will, however, have to undergo adaptations and improvements in order to meet future demands for both food security of the growing population and environmental conservation (Asch and Brueck, 2010).

Rice is a recent introduction to Ethiopia, its importance is well recognized as the production area coverage of about 10,000 ha in 2006 has increased to over 63,000 ha in 2018 (CSA 2019). The area coverage in domestic rice production has increased considerably linked with expansion of production in the wetland and upland areas with the introduction of suitable rice varieties for the different agro-ecologies. In line with the area expansion, the production levels have been increasing consistently over years. CSA (Central Statistical Authority) data indicate that rice production increased from 71,316.07 tons in 2008 to 171,854.1 tons in 2018. The number of farmers engaged in rice production has also grown year after year. Rice production has brought a significant change in the livelihood of farmers and created job opportunities for a number of citizens in different areas of the country. Currently, Amhara, Southern Nations, Nationalities and Peoples Region (SNNPR), Oromiya, Somali, Gambella, BeniShangul Gumuz, and Tigray regions are the rice producing areas in Ethiopia (MoARD, 2010). The Amhara region takes the lion's share of producing the crop and accounted for $65-81 \%$ of the area coverage and $78-85 \%$ of the production in the years 2016-2018 (CSA 2017, CSA 2018 and 2019). According to the report of MoARD (2010), the potential rice production area in Ethiopia is estimated to be over 5,590,895 ha. Most of Ethiopia's rice production potential area lies in the western part of the country. The national average yield of rice is about 2.8t ha-1 (CSA, 2018) which is lower compared to the world average productivity of 4.6 tones ha- ${ }^{1}$ (FAOSTAT, 2018). Weeds, pests, soil nutrient deficiencies and terminal moisture stress are the major causes of low rice productivity in Ethiopia (MoARD, 2010; Gebey et al., 2012).

Rice is generally established through direct seeding or by transplanting (Pandey and Velasco, 2002). Direct 
seeding is the practice of sowing seeds directly in the main field (Farooqa et al., 2011). On the other hand, transplanting is the practice of raising seedlings in a nursery and moving them into the main field. The major advantages of transplanting over direct seeding are better weed suppression and higher grain yield (Farooqa et al., 2011). In some temperate Asian countries such as Japan and Korea, transplanting rice helped farmers to deal with the low temperature that can adversely affect the performance of direct-seeded rice at higher altitudes (Pandey and Velasco, 2002). Transplanting has high labour demands for uprooting nursery seedlings, $\mathrm{p}$ uddling fields, and transplanting seedlings into fields (Farooqa et al., 2011).

Several researchers have emphasized the importance of seedling age and transplanting time on the performance of transplanted rice (Baloch et al., 2007, Mobasser et al., 2007, Ginigaddara and Ranamukhaarachchi, 2011). When seedlings are transplanted at the right time, tillering and growth proceed normally with uniform stand establishment (Mobasser et al., 2007). If the age of a seedling is more than optimum, the seedling produces fewer tillers thereby resulting in poor yield. According to Mobasser et al. (2007) seedlings older than 35 days led to more prolonged recovery from transplanting shock than younger seedlings. Baloch et al. (2007) indicated that, in addition to seedlings age, transplanting time determined rice yield. Transplanting at the optimum age of seedlings and time is important for ensuring less risk of crop failures in rainfed lowland environments. According to Azhiri et al. (2004) delayed transplanting particularly at an inappropriate seedling age resulted in adverse effects on rice yields due to the compound effect of late-season drought and heavy insect and pest infestations.

Ginigaddara and Ranamukhaarachchi (2011) reported that transplanted rice matured earlier and escaped terminal moisture stresses than direct seeded rice. Farmers in Fogera plains of northwestern Ethiopia generally establish rainfed lowland rice through broadcast direct seeding. Rice production in the study often faces the problem of terminal moisture stress owing to abrupt ending of rainfall at the reproductive and grain filling stages of the crop (Tilahun et al., 2012). The farmers spend much of their family labour and money on weeding. The average rice productivity of the area is 2.53 tha- $^{-1}$ and is much lower than the world's average rice productivity of 4.4 t ha-1 (MoARD, 2010; FAO, 2012) Terminal moisture stress, weeds and soil nutrient deficiencies are the major reasons for the low productivity of rice in Ethiopia (Tilahun et al., 2012). This research was therefore conducted to determine appropriate seedling age for transplanting for better rice production in Fogera Plains of northwestern Ethiopia.

\section{Material and Methods \\ 2.1 The Study Site}

Effect of rice Seedling age at transplanting experiment was conducted for two consecutive years (2018-2019)

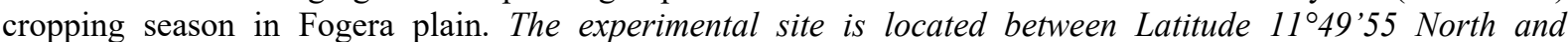
Longitude $37^{\circ} 37^{\prime} 40$ East at an altitude of 1815 meters above sea level. The study site receives averages mean annual rainfall, minimum and maximum temperature of $1219 \mathrm{~mm}, 12.75^{\circ} \mathrm{C}$ and $27.37^{\circ} \mathrm{C}$, respectively. The dominant soil type on the Fogera plains is black clay soil (ferric Vertisols) (Tilahun et al., 2012). The experimental soil was clayey in texture with a $\mathrm{pH}$ of 6.05 .

\subsection{Treatments and experimental design}

The treatments consists of six seedling ages 0 , (dry seed as a control) 7, (pre-germinated), 14, 21, 28, 35 days old seedlings were laid in RCB Design with three replications. The gross plot size was $4 \mathrm{~m} \times 3 \mathrm{~m}$ with $1 \mathrm{~m}$ spacing between plots and replications. Treatments were assigned to each plot randomly. Seeding at the nursery was staggered to coincide with the transplanting schedule. For field planting, seedlings were transplanted at the spacing of $25 \mathrm{~cm}$ between rows and $20 \mathrm{~cm}$ between plants. Three seedlings were planted per hill according to the planned treatment (Tilahun et al., 2013). The variety Edget was used for this experiment. Recommended fertilizer rates of 69/23 kg N/P2O5 ha- ${ }^{1}$ for each treatment was used (Tilahun et al., 2007)Urea fertilizer was applied for all the plots few days after transplanting just after the seedlings recover from the transplanting shook.

\section{Experimental Procedure}

\subsection{Nursery Management}

In order to raise the seedlings first a mixture of soil and rice husk at a ratio of 8:1 was prepared. Then the mixture was spread on the plastic covered seed bed at a thickness of about $5 \mathrm{~cm}$. The rice seeds were broadcasted at a rate of $25 \mathrm{~kg} \mathrm{seed} / 100 \mathrm{~m}^{2}$ seed bed. Finally the seeds were covered with very thin layer of soil and dry grass which was removed when the seeds started emerging. The seed bed was watered in the morning and night every day till the transplanting. Hand weeding was used to control the weeds from nursery field. It is necessary to develop the healthy \& weeds free nursery, which is essential to get maximum yield. Land was well prepared during puddling. 


\subsection{Data Collection and Measurement}

Data were collected from a net plot size of $3 \mathrm{~m} \times 2 \mathrm{~m}$ avoiding two rows from the left and two rows from the right as border rows and $50 \mathrm{~cm}$ from each of the top and bottom sides of the plots. Data was collected from the net plot area on plant height, Panicle length, number of total tillers $/ \mathrm{m}^{2}$, number of fertile panicle per $/ \mathrm{m} 2$, number of filled spiklets/panicle, thousand seeds weight, grain yield, straw yield and harvest index. The harvest index was calculated as the ratio of grain yield to biological yield following the equation:

$$
\text { Harvest index }=\frac{\text { Economic yield }}{\text { Biological yield }} \times 100
$$

All collected data were subjected to analysis of variance (ANOVA) using SAS software version 9.2 (SASInstitute, 2008). Wherever treatment differences are be found significant, mean separation of treatments would be calculated based on results of F-test and probability levels of 0.01 and 0.05 depending the results of the ANOVA. Economic analysis was performed following the partial budget analysis methodology of CIMMYT (1988). The cost of raising seedlings, transplanting, and weeding as well as market prices of grain and straw were considered for economic analysis. Labor cost of 50 Birr per man-day, rice grain price of 13.5 Birr per $\mathrm{kg}$, and straw price of 1.20 Birr per kg were considered in the economic analysis.

\subsection{Results and Discussions Plant height}

The results of the analysis of Variance Showed that (Table 1 and 2), the highest plant height $(97.0$ and $88.7 \mathrm{~cm})$ recorded from 21 and 14 days old seedling age in 2018 and 2019 growing season respectively. Whereas, the shortest Plant height was observed from dry sowing treatment $(74.9$ and $72.9 \mathrm{~cm})$ which was statistically similar in both years (Table 1 and 2) The combined analysis of variance over two years result indicated that effects of seedling age at transplanting very highly significantly affected Plant height $(\mathrm{p}<0.001)$ The taller plant height $(91.5 \mathrm{~cm})$ was recorded from 14 days old seedling age followed by 21 days seedling age (91.2) which were statistically similar (Table 3). On the other hand, the shortest plant height $(73.9 \mathrm{~cm}$ ) was obtained from the control treatment or Dry sowing (Table 3). The result indicated that plant height increased significantly by planting younger seedlings as compared to older. This might be due to higher phyllocrone production in younger seedlings before entering to reproductive stage, as well as less transplanting shock at this stage. These results are in line with Mishra and Salokhe (2008), who recorded more plant height after transplanting younger seedlings, as compared to older seedlings. Significant variation in plant height was also observed due to variation in seedling age (Khatun et al., 2002).

\section{Panicle Length}

Rice panicle length was significantly $(\mathrm{P}<0.01)$ responding to seedling age at transplanting (Table 1$)$. The longest panicle length $(18.8 \mathrm{~cm})$ was observed at 14 and 21 days old seedling age followed by 7 (pre-germinated), 28 and 35 days old seedling age $(18.0 \mathrm{~cm})$ respectively which was statistically similar in 2018 . The shortest panicle length $(15.7 \mathrm{~cm})$ was recorded from the control treatment (dry sowing).In addition to this the highest panicle length $(18.3$ and $17.7 \mathrm{~cm}$ ) was recorded from a younger seedling age of 14 and 21 days respectively in 2019 . The minimum panicle length of $(15.7 \mathrm{~cm})$ was obtained from 7 days seedling age (pre-germinated) and the control treatment which was statistically similar. The combined analysis of variance over two years result showed that effects of seedling age at transplanting highly significantly affected Plant height $(\mathrm{p}<0.01)$ The taller panicle length $(18.6 \mathrm{~cm})$ was recorded from 14 days old seedling age followed by 21 days seedling age (18.2.) (Table $3)$.On the other hand, the shortest panicle length $(15.7 \mathrm{~cm})$ was obtained from the control treatment or dry sowing followed by 7 days seedling age (pre-germinated seed (Table 3). The longest panicle length observed from 21 days old seedlings might be due to appropriate seedling age for transplanting as compared to older seedlings and direct seeded rice technology The result was in line with (Ginigaddara and Ranamukhaarachchi, 2011) who reported that seedling age is an important element affecting the number of filled grains per panicle, the panicle length, the 1000-grain weight and the grain yield in rice.

\section{Number of Tillers per $\mathbf{m}^{2}$}

The highest number of total tillers $/ \mathrm{m}^{2}$ (275) were observed in 21 days old seedling and were highly significantly different from all the other treatments and it is followed by 14 days seedling age (260) tillers per $\mathrm{m}^{2}$ in 2018 cropping season. However, the lowest number of total tillers per $\mathrm{m}^{2}$ (211 and 212) was recorded in pre geminated rice and farmer practice (control) treatments which was statistically similar. (Table 1) More over non significance difference among treatments were observed on number of total tillers per $\mathrm{m}^{2}$ in the year 2019 . (Table 2) The combined over two years analysis of variance result showed that effects of seedling age at transplanting very highly significantly affected number of tillers per $\mathrm{m}^{2}(\mathrm{p}<0.001)$ The Highest values of total tillers per $\mathrm{m}^{2}$ (268 and 265) was recorded from 21 and 14 days old seedling age which were statistically similar 
(Table 3) The lowest and statistically similar number of total tillers per $\mathrm{m}^{2}(216)$ was obtained from dry sowing method of planting (control) followed by the other treatments (Table 3). Overall younger seedlings produced higher numbers of tillers than older seedlings, which might be due to less root damage and minimum transplanting shock, as younger seedlings can more easily establish themselves after transplanting in the main field. These results were supported by Mishra and Salokhe (2008), who reported younger seedlings, produced a higher number of productive tillers after transplanting. These results are also supported by some research that reported positive increases in the number of tillers after transplanting younger seedlings in SRI (Ceesay et al., 2006; Kabir and Uphoff, 2007; Sinha and Talati, 2007).

\section{Number of fertile panicles per $\mathbf{m}^{2}$}

Effects of seedling age at transplanting statistically influenced Number of fertile panicles per $\mathrm{m}^{2}(\mathrm{P}<0.05)$. The highest number of fertile panicle per $\mathrm{m}^{2}$ (268) were recorded from 21 days old seedling age followed by 14 days seedling age (237). While statistically equivalent lowest value of fertile panicles per $\mathrm{m}^{2}$ (192 and 196) were obtained from the control and pre-germinated seed treatments in the year 2018. (Table 1).Moreover, the analysis of variance exhibited that seedling age at transplanting had significantly $(\mathrm{P}<0.05)$ influenced number of fertile panicle. The highest number of fertile panicle per $\mathrm{m}^{2}$ (259 and 256) was observed from 21 and 14 days old seedling age. .Moreover the lowest number of fertile panicle $/ \mathrm{m}^{2}$ (211 and 213) were observed from 28 days seedling age and dry sowing (control) treatments which were statistically similar in 2019 cropping season (Table 2) The combined analysis of variance over two years result showed that effects of seedling age at transplanting very highly significantly affected number of fertile panicle per $\mathrm{m}^{2}(\mathrm{p}<0.001)$. Highest values of $(263)$ fertile panicle per $\mathrm{m}^{2}$ were observed in 21 days seedling age which was statistically at par at 14 days old seedling age (247) (Table 3) whereas, the lowest number of fertile panicle per $\mathrm{m}^{2}$ (203)was observed from dry planting method followed by 2835 and 7 (pre-germinated seed) days old seedling age. (Table 3) This result may indicate that more transplanting shock that may have been suffered by older seedlings (28 and 35) old seedlings than the younger seedlings (14 and 21) day-old seedlings. In line with the present results, among the yield attributes, the number of productive tillers is an important agronomic trait, which finally determines the number of fertile panicles and grain yield per unit land area (Ginigaddara and Ranamukhaarachchi, 2011).

\section{Number of Filled grains /Panicle}

Data given in (Table 1) revealed that maximum number of filled grains per panicle (105) was produced by 21 days seedling age followed by 14 days seedling age (91) at transplanting which remained statistically similar. However, the lowest number of filled grains per panicle (70) was shown by dry planting (farmer practice) in the year 2018 (Table 1). The highest number of filled grain per panicle (90) in 2019 were observed from 21 days seedling age where as the lowest filled grain per panicle was observed from dry sowing (control treatment)(Table 2). The combined analysis over two years result showed that average highest number of filled grain per panicle (98 and 90) were obtained at 21 and 14 days seedling age respectively. More over the lowest number of filled grain per panicle (69) were exhibited from dry sowing or the control treatment followed by 35 , 28 days old seedlings (78 and 79) which was statistically similar respectively (Table 3 ). This result may be due to appropriate seedling age for transplanting produced more number of fertile panicles per $\mathrm{m}^{2}$ and leads to more number of filled grain per panicle These results are inconformity with (Ginigaddara and Ranamukhaarachchi, 2011; Tari, 2012). Khusrul and Aminul (2009) and Bagheri, et al. (2011) reported that more productive tillers and spikelets were obtained from transplanting 20-25-day-old seedlings. Overall, transplanting 21-day-old seedlings led to the production of higher numbers of filled grain per panicle than direct sowing of seed and other treatments.

\section{Grain yield $\mathbf{t} / \mathbf{h a}$}

Data show that seedling at transplanting highly and very highly significantly influenced grain yield in both years respectively (Table 1 and 2). Among the seedling age, in 2018, maximum yield was recorded in $\left(4.97 \mathrm{tha}^{-1}\right)$ from 21 days old seedling age followed by 35 days seedling age $\left(3.88 \mathrm{t} \mathrm{ha-}^{-1}\right)$ while the minimum value was found by dry seed sowing or the control treatments (3.01 t ha- $\left.{ }^{1}\right)$. As regarding from 2019 growing period, maximum grain yield was recorded in 21 days old seedling age (4.11 tha- $\left.{ }^{1}\right)$ followed by 14 days seedling age (3.85 $\left.\mathrm{t} \mathrm{ha}^{-1}\right)$, while the minimum yield was given by dry seed sowing or farmer practices $\left(2.68 \mathrm{t} \mathrm{ha-}^{1}\right)$ followed by 2835 and 7(pre-germinated seed) days old seedlings treatment $\left(2.70,2.71\right.$ and $\left.2.74 \mathrm{t} \mathrm{ha-}^{-1}\right)$. The combined effect over two years analysis on seedling age was also found to be highly significant $((\mathrm{p}<0.01)$. Maximum grain yield was recorded from 21 days seedling age (4.54 tha- $\left.{ }^{1}\right)$, which was significantly higher than all other treatments. The minimum value $\left(2.84 \mathrm{t} \mathrm{ha}^{-1}\right)$ was recorded from dry planting or the farmer practice which is lower than other treatments (Table 3). Statistically similar result were also observed from 2835 and pregerminated seed (7) days seedling age (Table 3) The highest grain yield obtained from 21-day-old seedlings might be attributed to the highest number of Total tillers $/ \mathrm{m}^{2}$, highest number of filled grains panicle, and the highest number of fertile panicle per $\mathrm{m}^{2}$ in this treatment. Overall, higher rice grain yield was observed with transplanting younger seedlings compared to direct seeding. The observed increase in grain yield in this study is in agreement with the results of Iqbal, et al. (2007) who reported that transplanting produced significantly higher 
grain yield than direct seeding. The increase in the grain yield in response to transplanting could be attributed to the production of increased productive tiller and fertile panicle numbers (Azhiri et al., 2004).

\section{Straw yield t/ha}

The rice straw yield was significantly affected by seedling age at transplanting $(\mathrm{P}<0.05)$ in both years (Table 1 and 2). Significantly higher straw yield (11.77 and 8.57 ton /ha) was obtained with 21 and 14 days old seedling age followed by 14 days seedling age ( 10.2 and 7.57 ton/ha) respectively. The lowest straw yield ( 7.05 and 5.58 ton/ha) were recorded from dry sowing and 35 days old seedlings (Table 1 and 2). The combined effect over two years analysis on seedling age was also found to be highly significant $((\mathrm{p}<0.05)$. Maximum straw yield was recorded from 21 days seedling age $\left(10.17 \mathrm{t} \mathrm{ha}^{-1}\right)$, which was statically similar with 14 days seedling age $(8.91 \mathrm{t}$ $\left.\mathrm{ha}^{-1}\right)$, The lowest value $\left(6.53 \mathrm{tha}^{-1}\right)$ was recorded from dry planting or the farmer practice which is lower than all other treatments (Table 3). This result might be due to transplanting of different seedling age produced highest number of tillers/m2, highest number of panicle length and highest HI value as compared to dry sowing or farmer practice. In consistent with the finding of Ahmad, et al. (2009) and Bagheri, et al. (2011) who reported that rice seedling age and transplanting time affected total dry biomass of the crop. This result is also in line with that of Ginigaddara and Ranamukhaarachchi (2011) who reported higher HI with transplanting than direct seeding.

\section{Thousand Grain weight $(g)$}

Data regarding 1000 grain weight presented in Table- 2 showed that significantly $(\mathrm{P}<0.05)$ responding to seedling age at transplanting in the year 2019 but non significance difference observed among treatments in the year 2018 cropping season (Table 1). The combined analysis of variance over two years result showed that effects of seedling age at transplanting significantly affected 1000 grain weight $(\mathrm{p}<0.05)$. Heavier grains of this parameter ( 35.8 and $35.4 \mathrm{~g}$ ) were achieved in 21 and 14 days old seedling age which was statistically similar (Table3). On the other hand, the lowest 1000 grain weight $(31.0$ and $31.7 \mathrm{~g}$ ) was obtained from 35 and 28 days seedling age respectively (Table 3 ). This result might be due to transplanting of healthy and younger seedlings with appropriate seedling age can produced a heavier grain weight .This result was in line with Faroog et al. (2007) reported no significant difference in 1000-grain weight by planting healthy and younger seedlings grown with seed priming.|Thousand seeds weight from the 21-day-old seedlings increased 1000 seed weight produced from plants established by direct sowing by about $2.9 \mathrm{~g}$. and $4.4 \mathrm{~g}$ from 35 days older seedlings. This result corroborates the findings of Ginigaddara and Ranamukhaarachchi, (2011) who reported greater thousand seeds weight with transplanting over direct seeding

Results of the economic analysis indicated that transplanting 21-day-old seedlings at transplanting exhibited the highest net benefit, which amounted to 75132.00 ha- $^{-1}$ Birr (Table 4). The lowest net benefit was obtained when Dry seed or farmer practices (Table 4). The low yield of rice currently obtained by farmers in the study area has left farmers with little economic benefits despite the high yield potential of the crop in the study area. Transplanting rice seedlings to production fields evidently enables escape of the crop plant from terminal moisture stresses and enhances grain and straw yields. Transplanting 21-day-old seedlings produced a $59.0 \%$ advantage in net benefit over direct seeding. The observed higher economic advantage that accrued from transplanting than direct seeding is in agreement with the results of this experiment, Akbar et al. (2007) reported a $40 \%$ increase and Baloch et al. (2007) reported a $60 \%$ economic advantage with transplanting compared to direct seeding. The authors attributed the economic advantages to the higher yield of rice and reduced weeding cost with the transplanting

\subsection{Conclusion}

Rice production through transplanting of seedlings at optimum age led to significantly earlier maturity than production of the crop through direct sowing of dry seeds. All improvements in the yield components of plants established from transplanting seedlings of the crop culminated in significantly increased grain yield and economic benefit over direct sowing. Finally, this experiment has revealed that significantly higher grain yields and better economic advantages in rice production are obtained by transplanting seedlings rather than by direct sowing of dry seed. Transplanting 21-day-old seedlings could, thus, be recommended for enhanced yield and increased farm income in the rain-fed lowland rice production system in the Fogera plains of northwestern Ethiopia. 
Table 1 Effects of Seedling age at Transplanting on Yield and Yield Components of Low Land Rice (Edget Var.) in Fogera plain Year 2018

\begin{tabular}{|l|l|l|l|l|l|l|l|l|l|}
\hline \multirow{2}{*}{ Treatments } & \multicolumn{6}{|c|}{ Yield and Yield Components of seedling age at Trans planting in low land rice (Edget) } \\
\cline { 2 - 12 } & $\mathrm{Ph}(\mathrm{cm})$ & $\mathrm{Pl}(\mathrm{cm})$ & $\mathrm{TT} / \mathrm{m}^{2}$ & $\mathrm{NFP} / \mathrm{m}^{2}$ & $\mathrm{NFG} / \mathrm{P}$ & Gy t/ha & Sy t/ha & TGW & $\mathrm{HI} \%$ \\
\hline 1-Dry Sowing & $74.9 \mathrm{c}$ & $15.7 \mathrm{~b}$ & $212 \mathrm{c}$ & $192 \mathrm{c}$ & $70 \mathrm{~b}$ & $3.01 \mathrm{c}$ & $7.05 \mathrm{c}$ & 31.8 & 43.0 \\
\hline 2-Pre germinated seed & $86.5 \mathrm{~b}$ & $18.0 \mathrm{a}$ & $211 \mathrm{c}$ & $196 \mathrm{c}$ & $95 \mathrm{a}$ & $3.64 \mathrm{cb}$ & $8.93 \mathrm{bc}$ & 34.6 & 41.1 \\
\hline 3-14 Days S.Age & $94.4 \mathrm{a}$ & $18.8 \mathrm{a}$ & $260 \mathrm{ba}$ & $237 \mathrm{ba}$ & $91 \mathrm{a}$ & $3.55 \mathrm{cb}$ & $10.25 \mathrm{ba}$ & 36.5 & 35.2 \\
\hline 4-21 Days S Age & $97.0 \mathrm{a}$ & $18.8 \mathrm{a}$ & $275 \mathrm{a}$ & $268 \mathrm{a}$ & $105 \mathrm{a}$ & $4.97 \mathrm{a}$ & $11.77 \mathrm{a}$ & 37.2 & 43.2 \\
\hline 5-28 Days S Age & $85.0 \mathrm{~b}$ & $18.0 \mathrm{a}$ & $209 \mathrm{c}$ & $200 \mathrm{bc}$ & $90 \mathrm{a}$ & $3.53 \mathrm{cb}$ & $9.26 \mathrm{bc}$ & 31.3 & 38.4 \\
\hline 6-35 Days S.Age & $86.0 \mathrm{~b}$ & $18.0 \mathrm{a}$ & $229 \mathrm{bc}$ & $217 \mathrm{bc}$ & $88 \mathrm{a}$ & $3.88 \mathrm{~b}$ & $9.19 \mathrm{bc}$ & 29.9 & 42.4 \\
\hline Sig.diff. & $* *$ & $*$ & $* *$ & $*$ & $*$ & $* *$ & $*$ & NS & NS \\
\hline CV & 4.43 & 5.53 & 9.07 & 10.4 & 11.0 & 12.7 & 13.3 & 11.9 & 19.0 \\
\hline
\end{tabular}

$P H=$ plant height $(\mathrm{cm}), P L=$ panicle length $(\mathrm{cm}), T T / \mathrm{m} 2=$ total tillers $/ \mathrm{m} 2, N F P=$ number of fertile panicles $/ m 2, N F G / P=$ number of filled grain per panicle, $G y=$ grain yield $\left(t h a^{-1}\right), S Y=$ straw yield $\left(t h a-^{l}\right)$, $T G W=$ thousand grain weight $(g), H I=$ harvest index $(\%), * *=$ highly significant at $P<0.01, *=$ significant at $P<0.05$, ns $=$ not significant at $P \geq 0.05$

Table 2 Effects of Seedling age at Transplanting on Yield and Yield Components of Low Land Rice (Edget Var.) in Fogera plain Year 2019

\begin{tabular}{|l|l|l|l|l|l|l|l|l|l|}
\hline \multirow{2}{*}{ Treatments } & \multicolumn{7}{|c|}{ Yield and Yield Components of seedling age at Trans planting in low land rice (Edget) } \\
\cline { 2 - 11 } & $\mathrm{Ph}(\mathrm{cm})$ & $\mathrm{Pl}(\mathrm{cm})$ & $\mathrm{TT} / \mathrm{m}^{2}$ & $\mathrm{NFP} / \mathrm{m}^{2}$ & $\mathrm{NFG} / \mathrm{P}$ & $\mathrm{Gy} \mathrm{t} / \mathrm{ha}$ & Sy $\mathrm{t} / \mathrm{ha}$ & $\mathrm{TGW}$ & $\mathrm{HI} \%$ \\
\hline 1-Dry Sowing & $72.9 \mathrm{c}$ & $15.7 \mathrm{~b}$ & $220 \mathrm{c}$ & $213 \mathrm{~b}$ & $67 \mathrm{c}$ & $2.68 \mathrm{~b}$ & $6.01 \mathrm{bc}$ & $33.3 \mathrm{ba}$ & 46.0 \\
\hline 2-Pre germinated seed & $73.4 \mathrm{c}$ & $15.7 \mathrm{~b}$ & $225 \mathrm{bc}$ & $221 \mathrm{ba}$ & $76 \mathrm{bac}$ & $2.74 \mathrm{~b}$ & $5.58 \mathrm{c}$ & $33.1 \mathrm{ba}$ & 49.0 \\
\hline 3-14 Days S.Age & $88.7 \mathrm{a}$ & $18.3 \mathrm{a}$ & $271 \mathrm{a}$ & $256 \mathrm{a}$ & $88 \mathrm{ba}$ & $3.85 \mathrm{a}$ & $7.57 \mathrm{ba}$ & $34.3 \mathrm{a}$ & 50.8 \\
\hline 4-21 Days S Age & $85.4 \mathrm{ba}$ & $17.7 \mathrm{a}$ & $261 \mathrm{ba}$ & $259 \mathrm{a}$ & $90 \mathrm{a}$ & $4.11 \mathrm{a}$ & $8.57 \mathrm{a}$ & $34.3 \mathrm{a}$ & 48.2 \\
\hline 5-28 Days S Age & $77.7 \mathrm{bc}$ & $16.6 \mathrm{~b}$ & $224 \mathrm{bc}$ & $211 \mathrm{~b}$ & $68 \mathrm{bc}$ & $2.71 \mathrm{~b}$ & $6.01 \mathrm{bc}$ & $32.1 \mathrm{~b}$ & 45.9 \\
\hline 6-35 Days S.Age & $76.6 \mathrm{c}$ & $17.8 \mathrm{a}$ & $233 \mathrm{bac}$ & $221 \mathrm{ba}$ & $67 \mathrm{c}$ & $2.70 \mathrm{~b}$ & $5.58 \mathrm{c}$ & $32.2 \mathrm{~b}$ & 49.1 \\
\hline Sig.diff. & $* *$ & $* *$ & $*$ & $*$ & $*$ & $* * *$ & $*$ & $*$ & NS \\
\hline CV & 5.97 & 3.53 & 9.25 & 10.25 & 14.7 & 9.55 & 15.1 & 2.61 & 11.9 \\
\hline
\end{tabular}

$P H=$ plant height $(\mathrm{cm}), P L=$ panicle length $(\mathrm{cm}), T T / \mathrm{m} 2=$ total tillers $/ \mathrm{m} 2, N F P=$ number of fertile panicles $/ m 2, N F G / P=$ number of filled grain per panicle, $G y=$ grain yield $(t$ ha-1), $S Y=$ straw yield $(t$ ha-1), $T G W=$ thousand grain weight $(g), H I=$ harvest index $(\%)$, *** = very highly significant at $P<0.001$, ** highly significant at $P<0.01, *=$ significant at $P<0.05, N S=$ not significant at $P \geq 0.05$

Table 3 Two years combined analysis 2018 and 2019 of Effects of Seedling age at Transplanting on Yield and Yield Components of Low Land Rice (Edget Var.) in Fogera plain

\begin{tabular}{|l|l|l|l|l|l|l|l|l|l|}
\hline \multirow{2}{*}{ Treatments } & \multicolumn{6}{|c|}{ Yield and Yield Components of seedling age at Trans planting in low land rice (Edget) } \\
\cline { 2 - 12 } & $\mathrm{Ph}(\mathrm{cm})$ & $\mathrm{Pl}(\mathrm{cm})$ & $\mathrm{TT} / \mathrm{m}^{2}$ & $\mathrm{NFP} / \mathrm{m}^{2}$ & $\mathrm{NFG} / \mathrm{P}$ & Gy t/ha & Sy t/ha & TGW $(\mathrm{g})$ & $\mathrm{HI} \%$ \\
\hline 1-Dry Sowing & $73.9 \mathrm{c}$ & $15.7 \mathrm{~d}$ & $216 \mathrm{~b}$ & $203 \mathrm{~b}$ & $69 \mathrm{c}$ & $2.84 \mathrm{c}$ & $6.53 \mathrm{c}$ & $32.5 \mathrm{ba}$ & 44.5 \\
\hline 2-Pre germinated seed & $80.0 \mathrm{cb}$ & $16.9 \mathrm{dc}$ & $218 \mathrm{~b}$ & $209 \mathrm{~b}$ & $86 \mathrm{ba}$ & $3.19 \mathrm{cb}$ & $7.25 \mathrm{bc}$ & $33.9 \mathrm{ba}$ & 45.0 \\
\hline 3-14 Days S.Age & $91.5 \mathrm{a}$ & $18.6 \mathrm{a}$ & $265 \mathrm{a}$ & $247 \mathrm{a}$ & $90 \mathrm{ba}$ & $3.70 \mathrm{~b}$ & $8.91 \mathrm{ba}$ & $35.4 \mathrm{a}$ & 43.0 \\
\hline 4-21 Days S A[ge & $91.2 \mathrm{a}$ & $18.2 \mathrm{ba}$ & $268 \mathrm{a}$ & $263 \mathrm{a}$ & $98 \mathrm{a}$ & $4.54 \mathrm{ba}$ & $10.17 \mathrm{a}$ & $35.8 \mathrm{a}$ & 45.7 \\
\hline 5-28 Days S Age & $81.3 \mathrm{~b}$ & $17.3 \mathrm{bc}$ & $217 \mathrm{~b}$ & $205 \mathrm{~b}$ & $79 \mathrm{bc}$ & $3.12 \mathrm{cb}$ & $7.63 \mathrm{bc}$ & $31.7 \mathrm{~b}$ & 42.2 \\
\hline 6-35 Days S.Age & $81.3 \mathrm{~b}$ & $17.9 \mathrm{bac}$ & $231 \mathrm{~b}$ & $219 \mathrm{~b}$ & $78 \mathrm{bc}$ & $3.29 \mathrm{cb}$ & $7.39 \mathrm{bc}$ & $31.0 \mathrm{~b}$ & 45.8 \\
\hline Sig.diff. & $* * *$ & $* *$ & $* * *$ & $* * *$ & $* *$ & $* *$ & $*$ & $*$ & NS \\
\hline CV & 7.61 & 5.66 & 8.64 & 10.1 & 15.5 & 16.0 & 24.0 & 8.44 & 17.3 \\
\hline
\end{tabular}

$P H=$ plant height $(\mathrm{cm}), P L=$ panicle length $(\mathrm{cm}), T T / \mathrm{m} 2=$ total tillers $/ \mathrm{m} 2, N F P=$ number of fertile panicles $/ m 2, N F G / P=$ number of filled grain per panicle, Gy = grain yield $(t$ ha-1), $S Y=$ straw yield $(t$ ha-1), $T G W=$ thousand grain weight $(\mathrm{g}), \mathrm{HI}=$ harvest index (\%), *** = very highly significant at $P<0.001$, ** highly significant at $P<0.01, *=$ significant at $P<0.05, N S=$ not significant at $P \geq 0.05$ 
Table 4. Effects of seedling age and planting time on economic benefit at Fogera in 2018 and 2019

\begin{tabular}{|l|c|c|c|c|c|c|c|}
\hline \multicolumn{1}{|c|}{ Treatments } & $\begin{array}{c}\text { Seed } \\
\text { cost } \\
\text { ETB ha- } \\
1\end{array}$ & $\begin{array}{c}\text { Nursery } \\
\text { cost } \\
\text { ETB ha- }\end{array}$ & $\begin{array}{c}\text { Planting } \\
\text { cost } \\
\text { ETB ha- }^{1}\end{array}$ & $\begin{array}{c}\text { Weeding } \\
\text { cost } \\
\text { ETB ha- }\end{array}$ & $\begin{array}{c}\text { Total variable } \\
\text { cost } \\
\text { ETB ha- }^{-1}\end{array}$ & $\begin{array}{c}\text { Gross } \\
\text { benefit } \\
\text { ETB ha- }^{-1}\end{array}$ & $\begin{array}{c}\text { Net } \\
\text { benefit } \\
\text { ETB ha- }^{-1}\end{array}$ \\
\hline Dry seed & 1350.00 & 0 & 900.00 & 2500.00 & 4750.00 & 49095 & 44345 \\
\hline $\begin{array}{l}\text { Pre-germinated } \\
\text { seed }\end{array}$ & 1350.00 & 0 & 1100.00 & 2500.00 & 4950.00 & 59856 & 54906 \\
\hline $\begin{array}{l}14 \text { days seedling } \\
\text { age }\end{array}$ & 337.50 & 1500.00 & 3000.00 & 1750 & 6587.50 & 60225 & 75382 \\
\hline $\begin{array}{l}21 \text { days seedling } \\
\text { age }\end{array}$ & 337.50 & 2500.00 & 2000.00 & 1000.00 & 5837.00 & 6088 & $\mathbf{7 5 1 3 2}$ \\
\hline $\begin{array}{l}28 \text { days seedling } \\
\text { age }\end{array}$ & 337.50 & 3500.00 & 1750.00 & 1250.00 & 6837.50 & 58767 & 51930 \\
\hline $\begin{array}{l}35 \text { days seedling } \\
\text { age }\end{array}$ & 337.50 & 4500.00 & 1750.00 & 1500.00 & 8087.50 & 63408 & 55321 \\
\hline
\end{tabular}

\subsection{References}

Ahmad A., Iqbal S., Ahmad S., Khaliq T., Nasim W., Hoogenboom G. (2009). Seasonal growth, radiation interception, its conversion efficiency and biomass production of Oryza sativa L. Under diverse agroenvironments in Pakistan. Pak. J. Bot., 41(3): 1241-1257.

Akbar E.N., Jabran K., Habib T. (2007). Comparison of different planting methods for optimization of plant population of fine rice (Oryza sativa 1.) in Punjab (Pakistan). Pak. J. Agric. Sci., 44(4): 597-599.

Asch, F. and Brueck H. 2010.Rice Crop Innovations and Natural-Resource Management: A Glimpse into the Future Presented at 2nd Africa Rice Congress: Innovations and Partnerships to Realize Africa Rice Potential, March 22-26. Mali: Bamako. Rice Research Conference, 16-19 September 2002, Beijing, China, pp 11-18

Azhiri S.T, Wade L.J., Mclaren C.G., Amarante S.T., Ramos C.G., Casimero M.C., Sebastian L.S. (2004). Delayed Planting of Rainfed Lowland Rice In Areas With Short-Season Rains. Philippine J. Crop Sci., 29(1): 51-58.

Azhiri S.T, Wade L.J., Mclaren C.G., Amarante S.T., Ramos C.G., Casimero M.C., Sebastian L.S. (2004). Delayed Planting of Rainfed Lowland Rice In Areas With Short-Season Rains. Philippine J. Crop Sci., 29(1): 51-58.

Baloch, M.S., Awan I.U., Hassan G., Zubair M. (2007). Studies on Plant Population and Stand Establishment Techniques for Increasing Productivity of Rice in Dera Ismail Khan, Pak. Rice Sci., 14(2): 118-124.

Carrijo, D.R., Lundy, M.E., Linquist, B.A. (2017). Rice yields and water use under alternate wetting and drying irrigation: a meta-analysis. Field Crops Res. 203, 173-180.

Ceesay, M., S.W. Reid, E.C.M. Fernandes, and N.T. Uphoff. 2006. The effect of repeated soil wetting and drying on low land rice yield with System of Rice Intensifcation (SRI) methods. International Journal of Agricultural Sustainability 4:5-14.

CIMMYT (1988). From Agronomic Data to Farmer Recommendations: An Economics Training Manual. Completely revised edition, Mexico, DF

CSA (Central Statistical Agency) (2017). Report on Area and Production of Major Crops (Private Peasant Holdings, Meher Season) The Federal Democratic Republic of Ethiopia Central Statistical Agency Agricultural Sample Survey Volume I, 2017 /18 (2010 E.C.) April, 2018. ADDIS ABABA, Ethiopia.

CSA (Central Statistical Agency) (2018). Report on Area and Production of Major Crops (Private Peasant Holdings, Meher Season) The Federal DemocraticRepublic of Ethiopia Central Statistical Agency Agricultural Sample Survey, Volume I, 2018 /19. April, 2019. ADDIS ABABA, Ethiopia.

CSA (Central Statistical Agency) (2019). Report on area and production of major crops (private peasant holdings, meher season). The federal democratic republic of Ethiopia central statistical agency agricultural sample survey 2018/19. Volume i. Statistical bulletin 589

Farooqa M.K., Siddique H.M., Rehman H., Aziz T., Lee D.J., Wahid A. (2011). Rice direct seeding: experiences, challenges and opportunities. Soil Till. Res., 111:87-98

Gebey T, Berhe K, Hoekstra D, Bogale A (2012). Rice value chain development in Fogera woreda based on the IPMS experience. Nairobi, Kenya: ILRI. 23pp.

Ginigaddara S.G.A., Ranamukhaarachchi S.L. (2011). Study of Age of Seedlings at Transplanting on Growth Dynamics And Yield of Rice Under Alternating Flooding And Suspension of Irrigation of Water Management. Recent Res. Sci. Technol., 3(3): 76-88.

Iqbal E., Ahmad A., Randhawa S.A. (2007). Effect Of Direct Seeding And Transplanting Methods On The Yield 
And Quality Of Fine Rice Basmati-370. Int. J. Agric. Biol., 3:251-252.

Kabir, H., and N. Uphoff. 2007. Results of disseminating the system of rice intensifcation with farmer feld school methods in Northern Myanmar. Experimental Agriculture 43:463-476.

Khatun, A., Mollah, M. I. U., Rashid, M. H., Islam, M. S. amd Khan, A. H. 2002. Seasonal effect of seedling age on the yield of rice. Pakistan J. Biol. Sci., 5(1): 40-42.

Khusrul A.K.M., Aminul M. (2009). Seedling Age Influence Rice (Oryza sativa L.) Performance. Philippine J. Sci., 138 (2): 219-226.

Mishra, A., and V.M. Salokhe. 2008. Seedling characteristics and the early growth of transplanted rice under different water regimes. Experimental Agriculture 44:365-383.

MoARD (2010). National Rice Research and Development Strategy of Ethiopia. The Federal Democratic Republic of Ethiopia, Ministry of Agriculture and Rural development, Addis Ababa, Ethiopia. $48 \mathrm{pp}$.

Mobasser H.R., Tari D.B., Vojdani M., Abadi R.S., Eftekhari A. (2007). Effect of seedling age and planting space on yield and yield components of rice. Asian J. Plant Sci., 6(2):438-440

Pandey S., Velasco L. (2002). Economics of direct seeding in Asia: patterns of adoption and research priorities. In: Pandey S, Mortimer M, Wade L, Tuong TP, Lopez K, Hardy B, editors. 2002. Direct seeding: research issues and opportunities. Proceedings of the International Workshop on Direct Seeding in Asian Rice Systems: Strategic Research Issues and Opportunities, 25-28 January 2000, Bangkok, Thailand. Los Baños(Philippines): International Rice Research Institute. Pp 3-14.

SAS (Statistical Analysis Software) Institute Inc. 2009.SAS/GRAPH 9.2: Reference, Fourth Edition. Cary, NC: SAS Institute Inc.

Sinha, S.K., and J. Talati. 2007. Productivity impacts of the system of rice intensifcation (SRI): A case study in West Bengal, India. Agricultural Water Management 87:55-60.

Subedi P, Shrawan KS, Santosh Ma, Dil RY (2019). Effects of Need-Based Nitrogen Management and Varieties on Growth and Yield of Dry Direct Seeded Rice. Pertanika J. Trop. Agric. Sc. 42 (2): 453 - 466.

Tari D.B. (2012). Determination of nitrogen fertilization effect at different transplanting dates on rice yield and yield traits. Am.-Eur. J. Agric. Environ. Sci., 12(5):678- 681.

Tilahun Gebey, Berhe, K., Hoekstra, D. and Alemu, B. 2012.Rice value chain development in Fogera woreda based on the IPMS experience. Nairobi, Kenya: ILRI.

Tilahun Tadesse, Minale Liben, Alemayehu Assefa and Zelalem Tadesse 2013. Effect of Transplanting on Rice in Northwestern Ethiopia Eth. J. Sci \& Technol., Vol. VI, no.1: 47-54, 2013 (C) Bahir Dar University

Tilahun Tadesse, MinaleLiben, AlemayehuAssefa, BelestiYeshalem and Tesfaye Wossen, 2007. Effect of nitrogen and phosphorus fertilizers on the yield of rice in Fogera and Metema areas. In: Ermiase A., Akalu T., Alemayehu A., Melaku W., Tadesse D., and Tilahun T. (eds.). Proceedings of the 1st Annual Regional Conference on Completed Crop Research Activities, 1417 August 2006. Amhara Regional Agricultural Research Institute, Bahir -Dar, Ethiopia.

USDA (United States Department of Agriculture). 2012. World agricultural production. Foreign Agricultural Service, Circular Series WAP 06-12. 